\title{
Accidental Displacement of Third Molar into the Sublingual Space: a Case Report
}

\author{
Rubens Jorge Silveira ${ }^{1}$, Robson Rodrigues Garcia ${ }^{1}$, Tessa Lucena Botelho ${ }^{2}$, Ademir Franco ${ }^{3}$, \\ Rhonan Ferreira Silva ${ }^{4,5}$ \\ ${ }^{1}$ Department of Maxillofacial Surgery, Paulista University, Brazil. \\ ${ }^{2}$ Department of Radiology, Paulista University, Brazil. \\ ${ }^{3}$ Department of Stomatology, School of Health and Biosciences, Pontifícia Universidade Católica do Paraná, Brazil. \\ ${ }^{4}$ Department of Legal Odontology, Federal University of Goias, Brazil. \\ ${ }^{5}$ Department of Legal Odontology, Paulista University, Brazil.
}

\author{
Corresponding Author: \\ Rubens Jorge Silveira \\ 74845-090, Rodovia BR-153, Km 503 - Fazenda Botafogo \\ Goiania, Goias \\ Brazil \\ Phone: 00556232394000 \\ Email: rubensjs30@hotmail.com.br
}

\begin{abstract}
Background: Successful extraction of third molars depends on preoperative diagnosis and planning. Gold standard preoperative examinations are performed through computed tomography, decreasing risks and avoiding potential accidents. The present report highlights the value of preoperative examinations in face of accidentally displaced third molars.

Methods: An 18-years-old female patient underwent a third mandibular molar extraction with a general dentist. Accidentally, the mandibular left third molar was displaced into the sublingual space, making necessary a second surgical step. The surgery was interrupted and the patient was referred to an expert in maxillofacial surgery.

Results: After 21 days awaiting an asymptomatic health status, the second surgical step was successfully performed using multislice computed tomography as preoperative imaging guide.

Conclusions: The present case report highlights the clinical usefulness of imaging planning and informed consents in face of legal and ethic potential complaints.
\end{abstract}

Keywords: third molar; multislice computed tomography; oral surgery; tooth extraction.

Accepted for publication: 29 August 2014

To cite this article:

Silveira RJ, Garcia RR, Botelho TL, Franco A, Silva RF. Accidental Displacement of Third Molar into the Sublingual Space: a Case Report.

J Oral Maxillofac Res 2014;5(3):e5

URL: http://www.ejomr.org/JOMR/archives/2014/3/e5/v5n3e5ht.pdf

doi: $10.5037 /$ jomr.2014.5305 


\section{INTRODUCTION}

In general, the third molar extraction is considered a procedure of minor proportion into the field of maxillofacial surgery. However, this procedure requires a specific surgical indication, planning, technical approach, and follow-up.

Transoperative accidents related to the extraction of third molars often involve fracture of the adjacent bone and teeth, laceration of soft tissue, haemorrhage, neural lesions, and dental displacement into the maxillary sinuses, extracranial fossae, and cervicofacial spaces [1]. Specifically in the medical literature, mandibular third molars were reported displaced into the infratemporal fossa [2]; the pterygomandibular fossa [3]; and the lateral pharyngeal [4]], submandibular $[\underline{5}, \underline{6}]$ and sublingual [7] spaces. In this context, the sublingual area is a triangular virtual space, located in the floor of the mouth, above the mylohyoid muscle, under the free portion of the tongue. The lateral limit of the sublingual space is the muscle complex hyoglossus-styloglossus, while the anterior limit is the genioglossus muscle []. Important morphologic structures are observed in the sublingual space, such as the duct of the submandibular salivary gland, branches of the lingual artery, and the lingual and hypoglossal neural bundles [7]. Thus, third molar extractions should be preferentially performed by maxillofacial surgeons, who are highly familiarized with the surgical morphology of head and neck. In addition, preoperative imaging must be properly used to avoid potential accidents in the routine of dental surgery. Based on that, the present study reports a case of a transoperative complication, in which a mandibular third molar was accidentally displaced into the sublingual space.

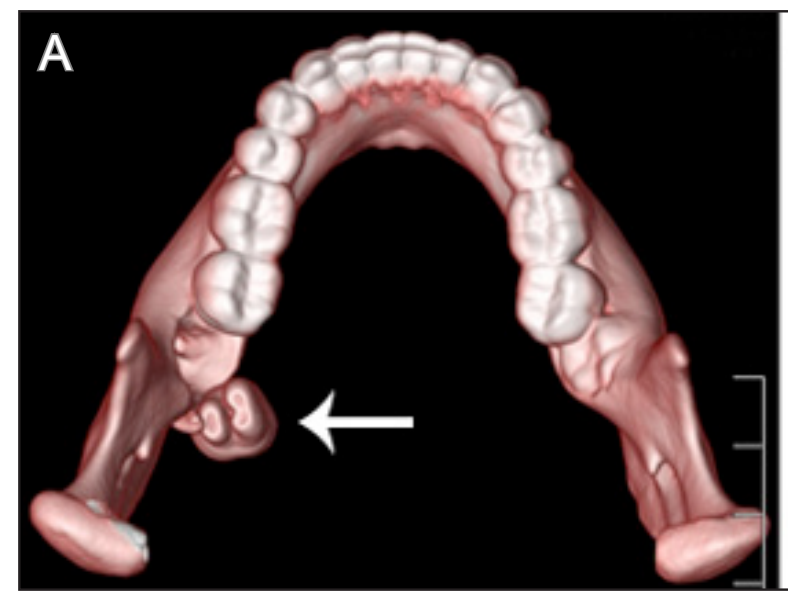

\section{CASE DESCRIPTION AND RESULTS}

In December, 2012, an 18-year-old female patient underwent extraction of the mandibular left third molar (tooth \#38) for orthodontic reasons. Accidentally, the tooth \#38 was displaced from the dental socket to an unknown adjacent site. The surgery was interrupted after the patient complains about the prolonged time taken to find the tooth. Anti-inflammatory (Ibuprofen $600 \mathrm{mg}$ ) on every 12 hours, and analgesic (Metamizole Sodium $500 \mathrm{mg}$ ) on every 6 hours, were prescribed covering a period of 3 days after the surgery. The patient was referred to a radiology clinic for a proper diagnosis by means of multislice computed tomography, using a Toshiba Aquilion $^{\odot}$ 64-channels (Toshiba Corporation ${ }^{\circ}$, Tokyo, Japan) device.

Three-dimensional reconstructions and axial and coronal slices enabled to detect the third molar in the medial surface of the left mandibular ramus in an inverted position (Figures 1 and 2). In addition, a detailed examination revealed that the third molar was displaced above the mylohyoid muscle, laterally to the tongue: into the sublingual space (Figure 3).

Despite advised about the importance of a second surgical intervention, the patient became apprehensive and uneasy in the following days. Additionally, functional and psychological conditions were worsened due to the presence of trismus, hampering daily activities. Based on that, the patient was convinced to undergo a second surgery only after 21 days from the accident. The second surgery was performed by an expert in the field of maxillofacial surgery. The surgical costs were afforded by the first dentist. During the preoperative examination the patient physical status was classified as ASA I, enabling the surgery.

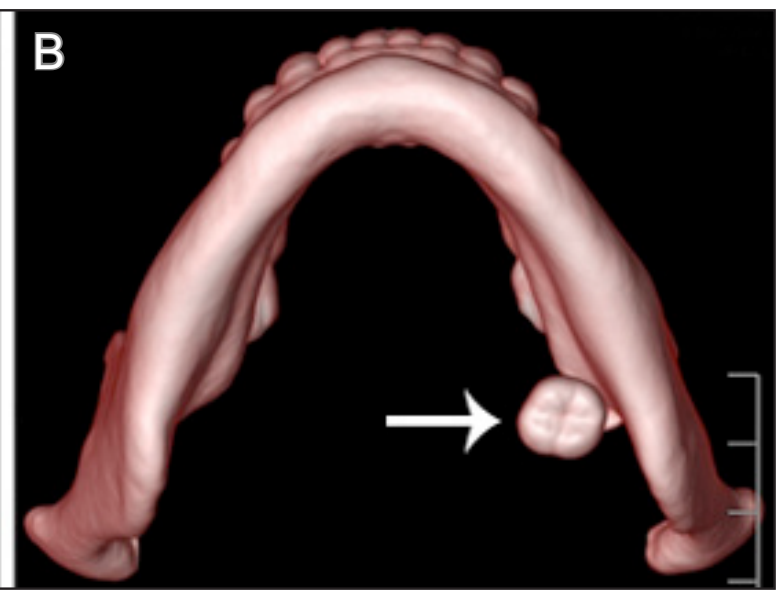

Figure 1. Superior (A) and inferior (B) views of the mandible, presented in three-dimensional reconstruction by means of multislice computed tomography, illustrating the position of the tooth \#38 (indicated by the arrows). 


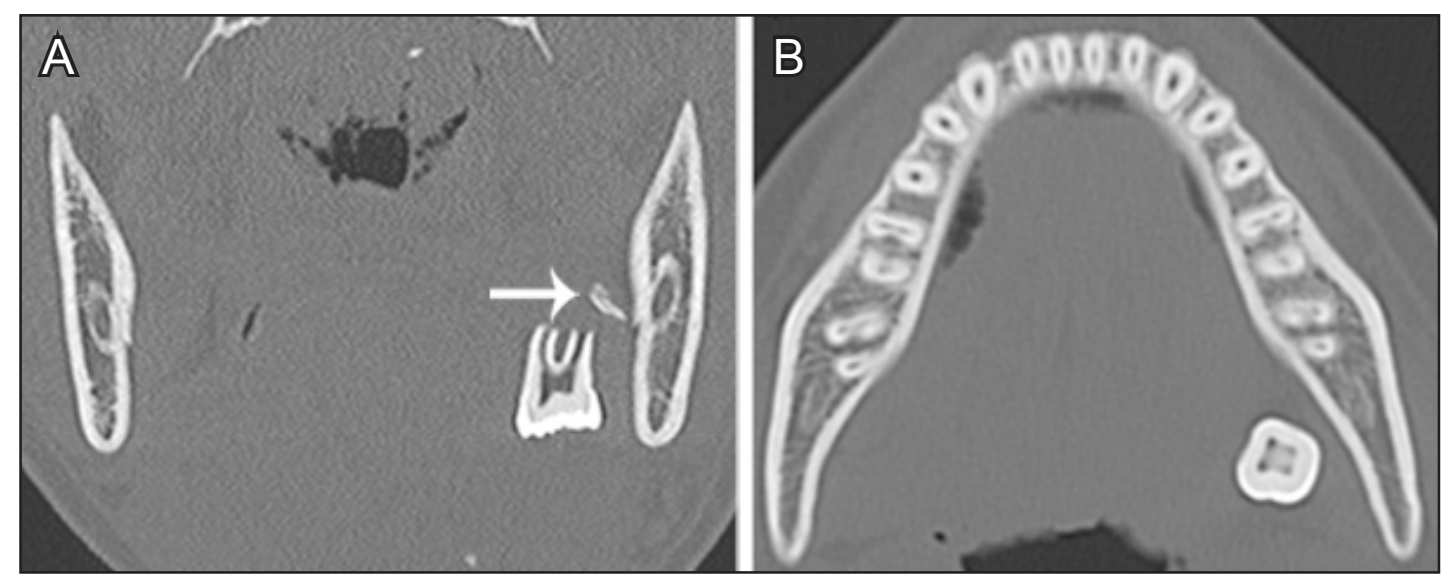

Figure 2. Axial (A) and coronal (B) views of the mandible, presented in two-dimensional slices for bone analysis by means of multislice computed tomography, revealing a small bone fragment of the left lingual cortical plate (indicated by the arrow), broken during the surgery.

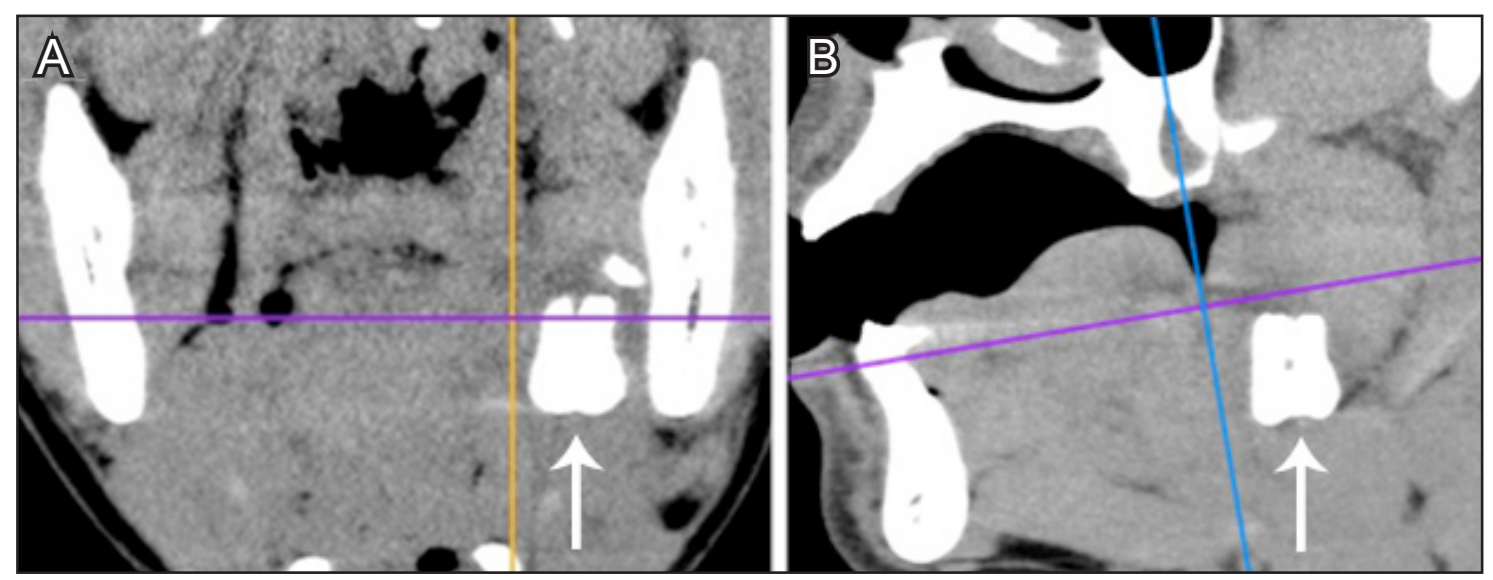

Figure 3. Coronal (A) and sagittal (B) views of the mandible, presented in two-dimensional slices for soft tissue analysis by means of multislice computed tomography, illustrating the relation between the tooth \#38 (indicated by the arrows) and the morphologic limits of the sublingual space.

Based on that, the patient was medicated with $8 \mathrm{mg}$ of orally administered corticosteroid dexamethasone 1 hour prior to the surgery, aiming optimal postoperative outcomes. The second surgical procedure was performed under mandibular nerve block, using Lidocaine $2 \%$ with adrenaline 1:100.000 (Nova DFL $^{\circ}$, Rio de Janeiro, Brazil). The third molar was accessed and successfully removed through an envelope incision, with a mucoperiosteal flap detachment from the retromolar trigone to the medial surface of the mandibular left first molar (tooth \#36).

In the following week the patient received the same medication prescribed in the first surgical attempt. Despite the close relation between the tooth \#38 and the submandibular salivary gland and the lingual nerve, the patient did not report postoperative sequels within a follow-up period of 45 days.

\section{DISCUSSION}

Displacement represents one of the most important accidents during the extraction of third molar due to the common need for major secondary surgical steps [2-6]. Additionally, accidentally displaced third molars may cause iatrogenic/traumatic neural injuries [9] and even temporomandibular joint pain and dysfunction [10]. The current literature reports the displacement of both maxillary and mandibular third molars. Specifically, Goméz-Oliveira et al. [11] described a case in which a maxillary third molar was displaced into the infratemporal fossa. Despite the close relation with the internal maxillary artery and the venous pterygoid plexus, the third molar was removed through a secondary surgical intervention, performed 2 weeks after the initial attempt, under local anesthesia. Similarly, Hoekema et al. [12] reported the accidental dental displacement into the same anatomic site. However, the authors state that asymptomatic patients could be treated with periodic clinical and radiographic follow-ups prior to additional invasive approaches. 
Yet in extractions of mandibular third molars, most of the accidents involve the displacement of dental roots. It is justified due to the tilted position in which mandibular third molars are often observed, which makes necessary the crown resection prior to the dental extraction [13]. Huang et al. [14] reported a case in which a third molar root was displaced into the pterygomandibular space. In this situation, the patient was successfully reoperated 5 months after the initial attempt, under general anesthesia and intraoral access. Similarly, Aznar-Arasa et al. [14] compiled 6 cases of third molar root displacement into the sublingual space. Specifically, the authors observed that 2 out of the 6 cases required a secondary intraoral surgical intervention for root retrieval. Both of the patients presented postoperative impairment of the inferior alveolar and lingual nerves. The other 4 patients were asymptomatic, excluding the need for a new surgery. Differently, in the present report an entire third molar was displaced into the sublingual space, indicating that the tooth was in a favourable position for extraction, in which the crown resection was not necessary. Besides, wrong surgical techniques are closely related to the transoperative displacement of third molars [15], potentially justifying the accident reported in our study. The same was observed in the reports of Pippi and Perfetti [16], and Olusanya et al. [17], in which general practitioners performed unsuccessful extractions, highlighting the relevance of not performing surgical interventions without having a proper expertise on the field. Based on that, we recommend that third molar extractions should be preferentially managed by maxillofacial surgeons for optimal surgical outcomes.

Considering the current literature, most of the third molars displacements into the sublingual space allows for a second surgical intervention under local anesthesia, making feasible a faster postoperative recovery, as observed in our study. An optimal postoperative recovery also depends on the technique addressed during the second approach for third molar removal. In some situations invasive techniques, such as double mucoperiosteal flaps, are necessary [16]; while in other cases high-tech performances, such as endoscopic-assisted retrieval, are feasible [18]. In the present case a single large mucoperiosteal surgical flap was necessary to reach the displaced third molar. Despite a close relation between the third molar and the submandibular salivary gland and the lingual nerve, no postoperative sequel was reported by the patient.

Independent from the situation, the level of surgical difficulty must be examined in forehand. Specifically, cases involving tilted and multiradicular third molars, and in close relation with neurovascular bundles, must detailed studied for an optimal surgical intervention. In this context, the radiographic surgical planning is the most adequate approach to avoid third molar accidental displacement [19]. Cone-beam and multislice computed tomography play an important role, allowing for detailed analysis through threedimensional reconstructions and slice navigation. In combination, the knowledge concerning the anatomy of head and neck is essential for an adequate and planned intervention.

In parallel to the surgical care, accidents involving iatrogenic performances must be promptly reported to the patient, or legal responsible, informing the patient's health status and treatment choices [20]. Thus, the bioethical principle of autonomy, which comprehends the patient's rights of being informed, and making decisions, is respected [21]. Above all, more important is the preoperative description of technical steps and potential risks, and further record of the patient's decision within a signed informed consent form $[21,22]$. Despite the best approach for clinical solutions involving iatrogenic performances, the dialogue not always avoids juridical complaints. In this context, the combination of preoperative imaging data, surgical plan, technical knowledge, informed consent, and the correct registration of the patient's files plays a valuable part as the main tool to support the professional against legal and ethic complaints.

\section{CONCLUSIONS}

Despite common in the routine of maxillofacial surgeons, the third molar extraction is subject to transoperative complications. Based on that, professionals must be aware to the fact of keeping patients informed prior to the technical procedure, and supported after the treatment. Additionally, the present case report highlights the importance of technically planning and performing oral surgeries; requesting and interpreting complementary exams; and registering the patient's consent; in face of legal and ethic potential complaints.

\section{ACKNOWLEDGMENTS AND DISCLOSURE STATEMENTS}

The authors report no conflicts of interest related to this study. 


\section{REFERENCES}

1. Azenha MR, Kato RB, Bueno RB, Neto PJ, Ribeiro MC. Accidents and complications associated to third molar surgeries performed by dentistry students. Oral Maxillofac Surg. 2013 Dec 27. [Epub ahead of print] [Medline: 24370576] [doi: 10.1007/s10006-013-0439-9]

2. Shahakbari R, Mortazavi H, Eshghpour M. First report of accidental displacement of mandibular third molar into infratemporal space. J Oral Maxillofac Surg. 2011 May;69(5):1301-3. Epub 2011 Jan 6. [Medline: 21211881] [doi: 10.1016/j.joms.2010.06.215]

3. Tumuluri V, Punnia-Moorthy A. Displacement of a mandibular third molar root fragment into the pterygomandibular space. Aust Dent J. 2002 Mar;47(1):68-71. [Medline: 12035962]

4. Medeiros N, Gaffrée G. Accidental displacement of inferior third molar into the lateral pharyngeal space: case report. J Oral Maxillofac Surg. 2008 Mar;66(3):578-80. [Medline: 18280399] [doi: 10.1016/j.joms.2005.10.042]

5. Huang IY, Wu CW, Worthington P. The displaced lower third molar: a literature review and suggestions for management. J Oral Maxillofac Surg. 2007 Jun;65(6):1186-90. Review. [Medline: 17517304]

6. Ozyuvaci H, Firat D, Tanyel C. Accidental displacement of a mandibular third molar: a case report. Quintessence Int. 2003 Apr;34(4):278-80. [Medline: 12731614]

7. Aznar-Arasa L, Figueiredo R, Gay-Escoda C. Iatrogenic displacement of lower third molar roots into the sublingual space: report of 6 cases. J Oral Maxillofac Surg. 2012 Feb;70(2):e107-15. [Medline: 22260911] [doi: 10.1016/i.joms.2011.09.039]

8. Souza RP, Paes Jr AJO, Volpato R. The sublingual space. Radiol Bras. 2003 Apr;36(1):35-40. Portuguese. [URL: http://ref.scielo.org/3r53j9] [doi: 10.1590/S0100-39842003000100009]

9. Mendes MB, de Carvalho Leite Leal Nunes CM, de Almeida Lopes MC. Anatomical relationship of lingual nerve to the region of mandibular third molar. J Oral Maxillofac Res. 2014 Jan 1;4(4):e2. [URL: http://www.ejomr.org/JOMR/archives/2013/4/e2/v4n4e2ht.htm] [Medline: 24478912] [PMC free article: 3681098] [doi: 10.5037/jomr.2013.4402]

10. Macfarlane TV, Blinkhorn AS, Stevenson LJ, Coulthard P. Third molar removal and orofacial pain: a population-based survey. J Oral Maxillofac Res. 2010 Oct 1;1(3):e4. [URL: http://www.ejomr.org/JOMR/archives/2010/3/e4/e4ht.htm] [Medline: 24421974] [PMC free article: 3886054] [doi: 10.5037/jomr.2010.1304]

11. Gómez-Oliveira G, Arribas-García I, Alvarez-Flores M, Gregoire-Ferriol J, Martínez-Gimeno C. Delayed removal of a maxillary third molar from the infratemporal fossa. Med Oral Patol Oral Cir Bucal. 2010 May 1;15(3):e509-11. [Medline: 20038889] [doi: 10.4317/medoral.15.e509]

12. Hoekema A, Apperloo RC, de Lange J. [A rare complication during the surgical removal of an impacted maxillary third molar]. Ned Tijdschr Tandheelkd. 2012 Jul-Aug;119(7-8):363-6. Dutch. [Medline: 22897034]

13. Huang IY, Chen CM, Chang SW, Yang CF, Chen CH, Chen CM. Surgical management of accidentally displaced mandibular third molar into the pterygomandibular space: a case report. Kaohsiung J Med Sci. 2007 Jul;23(7):370-4. [Medline: 17606433] [doi: 10.1016/S1607-551X(09)70424-3]

14. Aznar-Arasa L, Figueiredo R, Gay-Escoda C. Iatrogenic displacement of lower third molar roots into the sublingual space: report of 6 cases. J Oral Maxillofac Surg. 2012 Feb;70(2):e107-15. [Medline: 22260911] [doi: 10.1016/j.joms.2011.09.039]

15. Juodzbalys G, Daugela P. Mandibular third molar impaction: review of literature and a proposal of a classification. J Oral Maxillofac Res. 2013 Jul 1;4(2):e1. Review. [URL: http://www.ejomr.org/JOMR/archives/2013/2/e1/v4n2e1ht.htm] [Medline: 24422029] [PMC free article: 3886113] [doi: 10.5037/jomr.2013.4201]

16. Pippi R, Perfetti G. Lingual displacement of an entire lower third molar. Report of a case with suggestions for prevention and management. Minerva Stomatol. 2002 Jun;51(6):263-8. English, Italian. [Medline: 12147979]

17. Olusanya AA, Akadiri OA, Akinmoladun VI. Accidental displacement of mandibular third molar into soft tissue: a case report. Afr J Med Med Sci. 2008 Mar;37(1):77-80. [Medline: 18756859]

18. Engelke W, Fuentes R, Beltrán V. Endoscopically assisted removal of a lingually displaced third molar adjacent to the inferior alveolar nerve. J Craniofac Surg. 2013 Nov;24(6):2171-4. [Medline: 24220432] [doi: 10.1097/SCS.0b013e3182a2d834]

19. Agarwal AK, Kanekar SG. Submandibular and sublingual spaces: diagnostic imaging and evaluation. Otolaryngol Clin North Am. 2012 Dec;45(6):1311-23. Review. [Medline: 23153751] [doi: 10.1016/j.otc.2012.08.005]

20. Nusrath MA, Banks RJ. Unrecognised displacement of mandibular molar root into the submandibular space. Br Dent J. 2010 Sep 25;209(6):279-80. [Medline: 20871549] [doi: 10.1038/sj.bdj.2010.816]

21. Franco A, Alqerban A, Lima AAS, Tanaka OM, França BHS. The orthodontist's responsibility and the bioethical aspects in the current jurisprudence. Eur J Gen Dent. 2012 Sep;1(1):20-3.

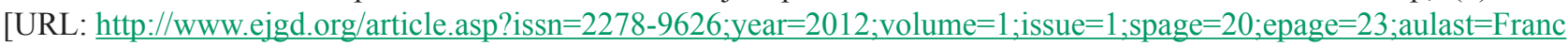
o\#ft13] [doi: 10.4103/2278-9626.101350]

22. Yalcin S, Aktas I, Emes Y, Atalay B. Accidental displacement of a high-speed handpiece bur during mandibular third molar surgery: a case report. Oral Surg Oral Med Oral Pathol Oral Radiol Endod. 2008 Mar;105(3):e29-31. [Medline: 18280942] [doi: 10.1016/j.tripleo.2007.09.017] 


\section{To cite this article:}

Silveira RJ, Garcia RR, Botelho TL, Franco A, Silva RF. Accidental Displacement of Third Molar into the Sublingual Space: a Case Report.

J Oral Maxillofac Res 2014;5(3):e5

URL: http://www.ejomr.org/JOMR/archives/2014/3/e5/v5n3e5ht.pdf

doi: $10.5037 /$ jomr.2014.5305

Copyright (C) Silveira RJ, Garcia RR, Botelho TL, Franco A, Silva RF. Published in the JOURNAL OF ORAL \& MAXILLOFACIAL RESEARCH (http://www.ejomr.org), 1 October 2014.

This is an open-access article, first published in the JOURNAL OF ORAL \& MAXILLOFACIAL RESEARCH, distributed under the terms of the Creative Commons Attribution-Noncommercial-No Derivative Works 3.0 Unported License, which permits unrestricted non-commercial use, distribution, and reproduction in any medium, provided the original work and is properly cited. The copyright, license information and link to the original publication on (http://www.ejomr.org) must be included. 